\title{
Activation of PKC- $\varepsilon$ counteracts maturation and apoptosis of HL-60 myeloid leukemic cells in response to TNF family members
}

\author{
A. Gonelli, ${ }^{1}$ D. Milani, ${ }^{1}$ E. Rimondi, ${ }^{2}$ R. Voltan, ${ }^{2}$ V. Grill, ${ }^{3}$ C. Celeghini ${ }^{3}$ \\ ${ }^{1}$ Department of Morphology and Embryology, University of Ferrara, Ferrara; ${ }^{2}$ Interdepartmental Center of \\ Molecular Medicine, University of Trieste, Trieste; ${ }^{3}$ Department of Biomedicine, University of Trieste, \\ Trieste, Italy
}

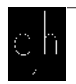

(C)2009 European Journal of Histochemistry

Protein kinase $C$ (PKC)- $\varepsilon$, a component of the serine/threonine PKC family, has been shown to influence the survival and differentiation pathways of normal hematopoietic cells. Here, we have modulated the activity of PKC- $\varepsilon$ with specific small molecule activator or inhibitor peptides. PKC- $\varepsilon$ inhibitor and activator peptides showed modest effects on HL-60 maturation when added alone, but PKC- $\varepsilon$ activator peptide significantly counteracted the pro-maturative activity of tumor necrosis factor (TNF)- $\alpha$ towards the monocytic/macrophagic lineage, as evaluated in terms of CD14 surface expression and morphological analyses. Moreover, while PKC- $\varepsilon$ inhibitor peptide showed a reproducible increase of TNF-related apoptosis inducing ligand (TRAIL)-induced apoptosis, PKC- $\varepsilon$ activator peptide potently counteracted the pro-apoptotic activity of TRAIL. Taken together, the anti-maturative and anti-apoptotic activities of PKC- $\varepsilon$ envision a potentially important proleukemic role of this PKC family member.

Key words: acute myeloid leukemia, surface antigens, HL-60 cells, apoptosis, maturation.

Correspondence: Arianna Gonelli,

Department of Morphology and Embryology, University of Ferrara, Via Fossato di Mortara 66, 44100 Ferrara, Italy.

Tel.: 39.0532.455572.

Fax: 39.0532.207351.

E-mail: arianna.gonelli@unife.it

Paper accepted on July 23, 2009

European Journal of Histochemistry

2009; vol. 53 issue 3 (July-September): 177-182
A ctivation of all protein kinase C (PKC) family of serine and threonine isoenzymes is associated with binding to the negatively charged phospholipids, phosphatidylserine, while different $\mathrm{PKC}$ isozymes have varying sensitivities to $\mathrm{Ca}^{2+}$ and lipid-derived second messengers such as diacylglycerol (Gonelli et al., 2009). Upon activation, PKC isozymes translocate from the soluble to the particulate cell fraction, including cell membrane, nucleus and mitochondria (Gonelli et al., 2009). PKC primary sequence can be broadly separated into two domains: the $\mathrm{N}$-terminal regulatory domain and the conserved C-terminal catalytic domain. The regulatory domain of PKC is composed of the $\mathrm{C} 1$ and $\mathrm{C} 2$ domains that mediate PKC interactions with second messengers, phospholipids, as well as inter and intramolecular protein-protein interactions. Differences in the order and number of copies of signaling domains, as well as sequence differences that affect binding affinities, result in the distinct activity of each PKC isozyme (Gonelli et al., 2009).

In recent years, a series of peptides derived from PKC have been shown to modulate its activity by interfering with critical protein-protein interactions within PKC and between PKC and PKC-binding proteins (Brandman et al., 2007, Souroujon and Mochly-Rosen, 1998). Focusing on PKC- $\varepsilon$ isozyme and using a rational approach, one C2-derived peptide that acts as an isozyme-selective activator (Dorn et al., 1999) and another that acts as a selective inhibitor (Johnson et al., 1996) of PKC- $\varepsilon$, have been identified. These findings are particularly interesting since besides being involved in the physiology of normal cardiac (Braun and MochlyRosen, 2003, Johnson et al., 1996, Li et al., 2006), hematopoietic (Gobbi et al., 2009, Mirandola et al., 2006, Racke et al., 2001), and neuronal (Borgatti et al., 1996) cell models, mounting experimental evidences have linked altered $\mathrm{PKC}-\varepsilon$ functions to 
solid tumor development (Okhrimenko et al., 2005, Gillespie et al., 2005, Lu et al., 2006). Therefore, taking advantage of the recent availability of small molecule peptides able to activate or inhibit specifically $\mathrm{PKC}-\varepsilon$ by disrupting protein/protein interactions (Dorn et al., 1999, Johnson et al., 1996), which open important therapeutic perspectives, we have investigated the effects of both PKC- $\varepsilon$ activator and $\mathrm{PKC}-\varepsilon$ inhibitor peptides on the maturation and survival of leukemic cells, using as a model system the HL-60 myeloblastic leukemia cell line, which can be induced to undergo terminal differentiation or apoptotic cell death by a variety of chemical and biological agents (Breitman et al., 1980, Zauli et al., 1996).

\section{Materials and Methods}

\section{Cells and reagents}

HL-60 cells, were cultured in RPMI-1640 (Gibco $\mathrm{BRL}$, Grand Island, NY) supplemented with 10\% fetal bovine serum (FBS; Gibco) and seeded at an optimal cell density of $0.8-1.0 \times 10^{6}$ cells $/ \mathrm{mL}$ before treatments. A PKC- $\varepsilon$-selective agonist octapeptide, $\psi \varepsilon$ receptor for activated C-kinase ( $\psi \varepsilon$ RACK), derived from a $P K C-\varepsilon$ sequence homologous to its anchoring protein, RACK- $\varepsilon$ : [HDAPIGYD; PKC- $\varepsilon$ (85-92)], was synthesized and purified (97\%) at Inbios S.r.l. (Napoli, Italy). A PKC- $\varepsilon$-selective antagonist peptide, eV1-2 [(EAVSLKPT; PKC- $\varepsilon$ (14-21)], and a negative control peptide, scrambled eV1-2 (LSETKPAV), were purchased from Calbiochem (Darmstadt, Germany).

HL-60 cells were treated with predetermined optimal concentrations of PKC- $\varepsilon$ agonist octapeptide (activator), PKC- $\varepsilon$ antagonist peptide (inhibitor) and scrambled peptide (22 $\mu \mathrm{g} / \mathrm{mL})$; recombinant TNF-related apoptosis inducing ligand (TRAIL) $(0.1 \mu \mathrm{g} / \mathrm{mL})$, prepared as previously described (Zauli et al., 2003), or recombinant tumor necrosis factor (TNF)- $\alpha$ $(0.1 \mu \mathrm{g} / \mathrm{mL}$ ) (R\&D Systems, Minneapolis, MN, USA), used either alone or in combination. In some experiments, $\mathrm{HL}-60$ were treated with $10^{-7}$ $M$ phorbol myristate acetate (PMA), purchased from Sigma Chemicals (Minneapolis, MN). The PKC $-\varepsilon$ catalytic activity was evaluated by using the PKC $\varepsilon$ KinEASE TM FP fluorescein green assay kit, used according to the manufacturer's instructions (Millipore, Billerica, MA, USA).

\section{Assessment of cell maturation and apoptosis}

At different times (1-3 days) post-treatment with PKC- $\varepsilon$ activator and inhibitor peptides, TNF- $\alpha$ or TRAIL, both maturation-inducing activity and cytotoxicity were assessed. In particular, samples were analyzed by: (1) monitoring cell surface antigen expression of CDI4 and CDIlb myeloid antigens (Todd et al., 1981, Zhang et al., 1994); (2) evaluating the degree of apoptosis by Annexin V/propidium iodide (PI) double staining and flow cytometry analysis and/or poly(ADP)ribose polymerase (PARP) cleavage in Western blot, as previously described (Borgatti et al., 1997, Vitale et al., 1997). For flow cytometry analyses, both the Annexin V-fluorescein isothiocyanate (FITC)/PI apoptosis kit and the CDIlb and CD14 phycoerythrin (PE) or FITC-conjugated antibodies (Abs) were purchased from Immunotech (Marseille, France). Unspecific fluorescence was assessed by using isotype-matched controls; (3) examining the morphology of the cells by staining with May-Grunwald-Giemsa solution followed by light microscopy examination (Secchiero et al., 2002, Secchiero et al., 2007); (4) counting the total number of viable cells by trypan blue dye exclusion; (5) using the 3-(4,5-dimethilthiazol-2yl)-2,5diphenyl tetrazolium bromide (MTT) colorimetric assay (Roche Diagnostics Corporation, Indianapolis, IN, USA).

\section{Western blot analysis}

Cells were lysed in a buffer containing $50 \mathrm{mM}$ Tris$\mathrm{HCl}, \mathrm{pH} 8.0,250 \mathrm{mM} \mathrm{NaCl}, 0.5 \% \mathrm{NP40}$, $2 \mathrm{mM}$ sodium orthovanadate, $1 \mathrm{mM}$ phenylmethylsulfonyl fluoride (PMSF), and $2 \mu \mathrm{g} / \mathrm{mL}$ of pepstatin. For Western blot analysis, 50-70 $\mu \mathrm{g}$ of protein were resolved on SDS-polyacrylamide gels and transferred to nitrocellulose membranes. Blots were incubated with monoclonal Abs anti-DNA repair enzyme PARP (Santa Cruz Biotechnology, Santa Cruz, CA, USA) or anti-actin (Sigma Aldrich, St. Louis, MO, USA) used for loading control (Milani et al., 2003). Membranes were washed and further incubated for one hour at room temperature with peroxidase-conjugated secondary Ab (Sigma). Detection was then performed using the Renaissance chemiluminescent ECL kit (NEN Dupont, Boston, MA, USA). Protein levels were densitometrically analysed by the ImageQuant software (Molecular Dynamics, Sunnyvale, CA, USA). Multiple film exposures were used to verify the linearity of the samples analyzed and to avoid saturation of the film. 


\section{Statistical analysis}

Data were analyzed using the two-tailed Student's t-test. Statistical significance was defined as $p<0.05$.

\section{Results}

\section{PKC- $\varepsilon$ activator peptide counteracts maturation induced by TNF- $\alpha$}

The effect of pre-determined optimal concentrations of specific peptides to modulate the catalytic activity of $\mathrm{PKC}-\varepsilon$ was initially evaluated by using a kit assay specific for $P K C-\varepsilon$. As shown in Figure 1 , the PKC- $\varepsilon$ activator peptide significantly $(p<0.05)$ promoted $\mathrm{PKC}-\varepsilon$ catalytic activity. On the other hand, the $\mathrm{PKC}-\varepsilon$ inhibitor peptide depressed the basal levels of $P K C-\varepsilon$ catalytic activity and profoundly inhibited $(p<0.05)$ the activation of $\mathrm{PKC}-\varepsilon$ induced by PMA. Since an important anti-leukemic strategy is to promote terminal growth arrest and maturation of acute myeloid leukemia (AML) blasts, in the first group of experiments, we have investigated whether the PKC$\varepsilon$ activator and inhibitor peptides were able to modulate the phenotypic profile and morphology of HL-60 cells, after treatment with TNF- $\alpha$, which represents a powerful inducer of maturation along the monocytic/ macrophagic lineage (Secchiero et al., 2003). As shown in Figure 2A and 2B, TNF- $\alpha$ markedly up-regulated the surface expression of CD14, which repre-

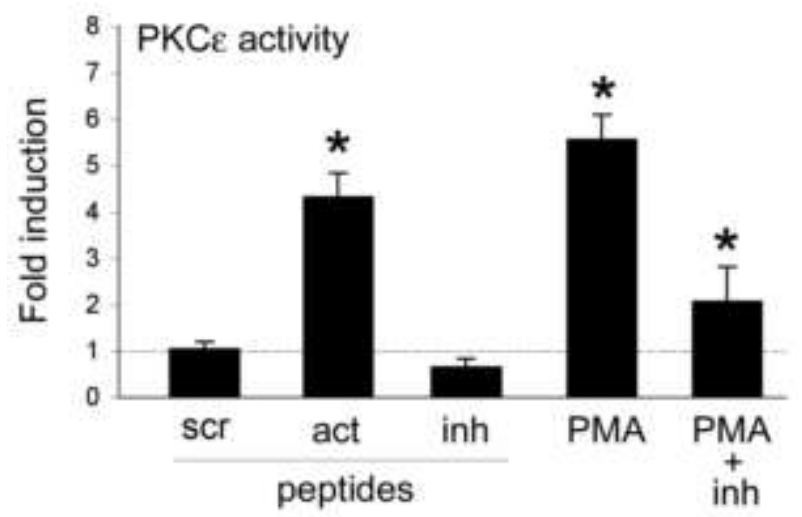

Figure 1. Validation of the PKC- $\varepsilon$ activator and inhibitor peptides in HL-60 cells. HL-60 cells were incubated with pre-determined optimal concentrations $(22 \mu \mathrm{g} / \mathrm{mL})$ of PKC- $\varepsilon$ activator (act) or inhibitor (inh) peptides, or with scrambled (scr) peptides used as negative controls for $\mathbf{8}$ hours. In parallel, PMA was used as positive control, for its ability to activate PKC- $\varepsilon$. PKC- $\varepsilon$ catalytic activity, evaluated as described in Materials and Methods, is expressed as fold of PKC- $\varepsilon$ activation with respect to control untreated cultures. Data represent the means \pm SD of three independent experiments. ${ }^{*} p<0.05$.
A

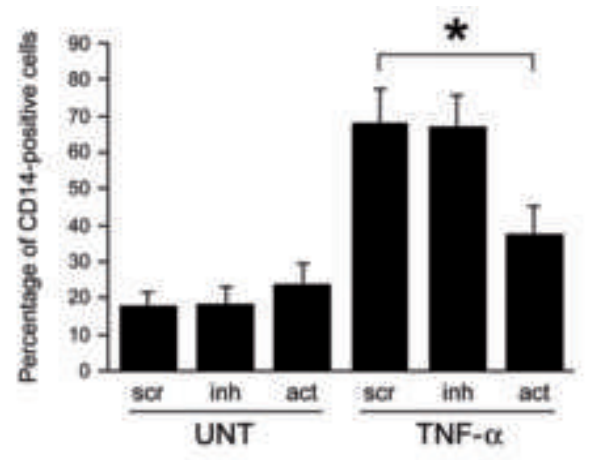

B

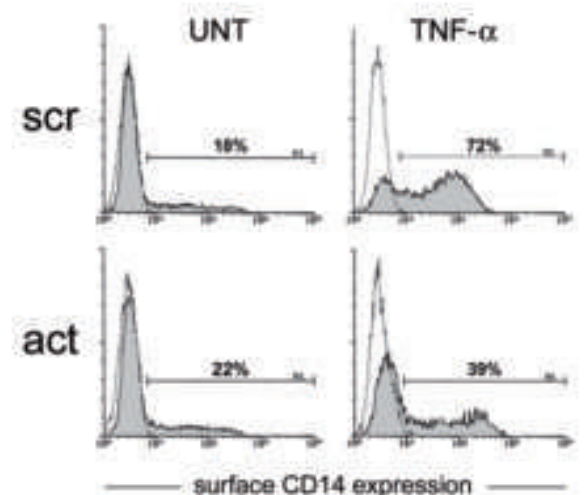

C

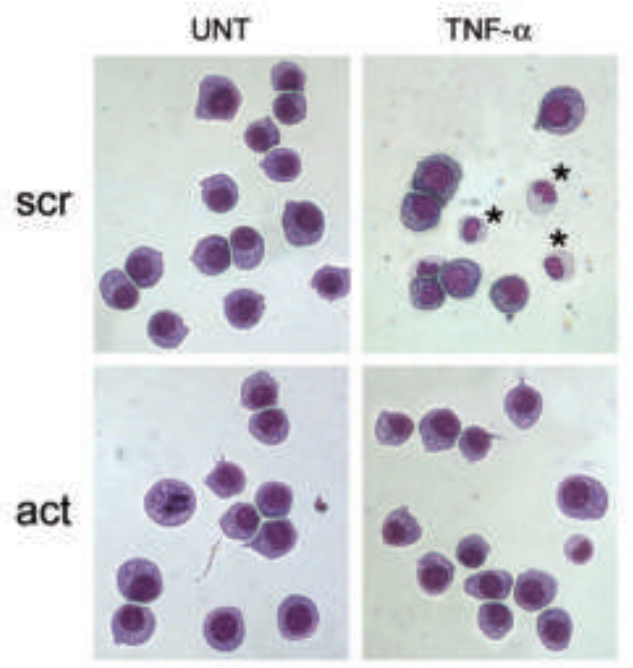

Figure 2. Maturative effect of TNF- $\alpha$, PKC- $\varepsilon$ activator and inhibitor peptides on HL-60 cells. HL-60 cells were incubated with control scrambled (scr), PKC- $\varepsilon$ activator (act) or inhibitor (inh) peptides $(22 \mu \mathrm{g} / \mathrm{mL})$, used alone or in combination with TNF- $\alpha(10 \mathrm{ng} / \mathrm{mL})$ for 72 hours and then analyzed for the surface expression of CD14 myeloid antigen, by flow cytometry analysis, and for cell morphology, by microscopic examination. In A, CD14 surface expression is reported as percentage of positive cells, and data are expressed as the mean \pm SD of five independent experiments performed in duplicate. ${ }^{\star} p<0.05$. In $\mathrm{B}$, a representative experiment is shown: shadowed histograms represent cells stained with Abs specific for the indicated surface antigen, whereas unshadowed histograms represent the background fluorescence obtained from the staining of the same cells with isotypematched control Abs. In C, the effects of TNF- $\alpha$ and PKC- $\varepsilon$ activator peptide on cell morphology are shown. HL-60 cells were stained with May-Grünwald-Giemsa solution: asterisks indicate cells with monocytic morphology. Representative fields of five separate experiments are shown. Original magnification: X400. UNT $=$ untreated cells. 
sents an excellent marker of monocytic maturation since it is undetectable on the surface of monocyte precursors and increases dramatically during their differentiation to monocytes (Todd et al., 1981; Zhang et al., 1994). While PKC-E inhibitor peptide had negligible effects on TNF- $\alpha$-induced up-regulation of CD14, PKC- $\varepsilon$ activator peptide significantly $(p<0.05)$ counteracted the TNF- $\alpha$ up-regulation of CD14 (Figure 2A-2B). Similarly, PKC- $\varepsilon$ activator peptide almost abrogated the TNF- $\alpha$ up-regulation of $\mathrm{CDIlb}$, used as additional surface marker of monocytic maturation (Secchiero et al., 2002). To confirm these flow cytometric results by morphological analyses, after 3 days of treatment with TNF- $\alpha$ plus PKC$\varepsilon$ peptides, HL60 cells were cytocentrifuged and then stained with May-Grunwald-Giemsa solution before light microscopy examination. As shown in Figure 2C, TNF- $\alpha$ plus $\mathrm{PKC}-\varepsilon$ activator peptide treated cultures showed a decrease of cells with monocytic features, such as condensation and cleavage of the nucleus, with respect to TNF- $\alpha$ alone.

\section{PKC- $\varepsilon$ activator peptide counteracts the pro-apoptot- ic activity of recombinant TRAIL}

Since the TNF family member TRAIL is a promising therapeutic agent for its ability to induce apoptotic cell death in a variety of tumor cells, including leukemias (Zauli and Secchiero, 2006), we performed additional experiments to evaluate the effects of combined treatments with either PKC- $\varepsilon$ activator or PKC- $\varepsilon$ inhibitor peptides plus recombinant TRAIL on the induction of HL-60 cell apoptosis, evaluated by Annexin V/PI double staining and flow cytometry analysis. Increasing doses of recombinant TRAIL were tested, in order to identify the concentration ( $100 \mathrm{ng} / \mathrm{mL}$ ) able to promote a significant increase of HL-60 apoptosis without inducing the maximal apoptotic response (Figure

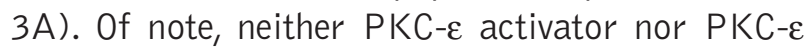
inhibitor peptides used alone showed significant effects on HL-60 viability and apoptosis. When used in combination with TRAIL, the PKC- $\varepsilon$ inhibitor peptide modestly but reproducibly $(p<0.05)$ increased the percentage of apoptosis in response to TRAIL (Figure 3B). Conversely, PKC- $\varepsilon$ activator peptide significantly $(p<0.05)$ counteracted the ability of TRAIL to induce apoptosis (Figure 3B). The ability of these peptides to modulate the apoptotic activity of TRAIL was also confirmed by Western blot analysis of PARP cleavage, a target of caspase activity (Figure $3 \mathrm{C}$ ).
A

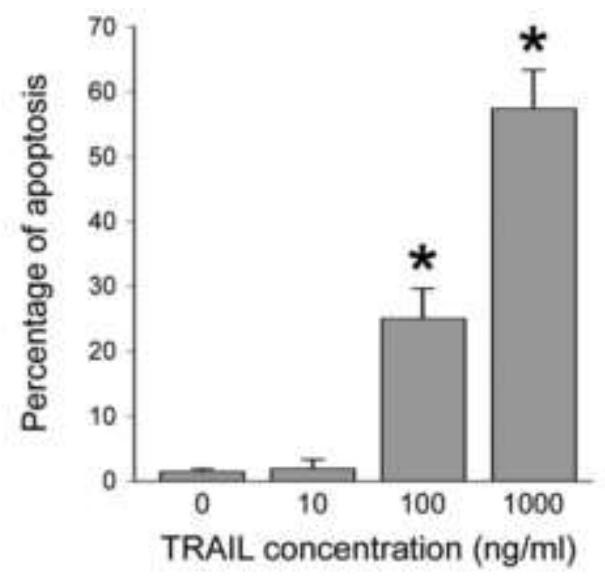

B

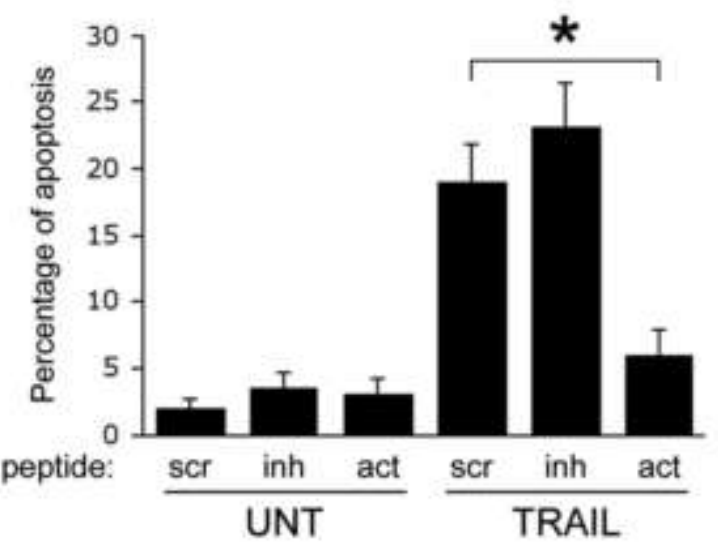

C

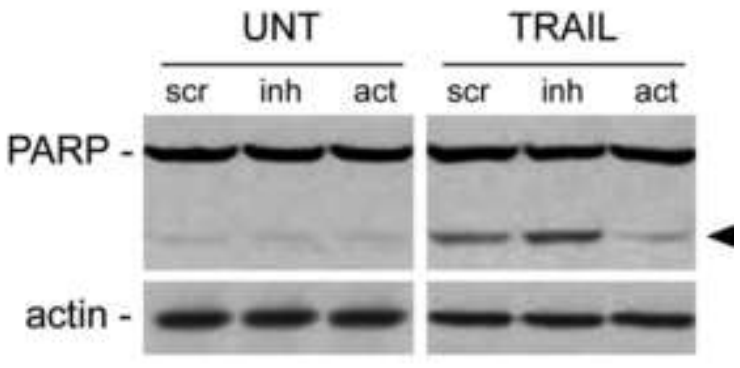

Figure 3. Effect of PKC- $\varepsilon$ activator and inhibitor peptides on TRAIL-mediated cytotoxicity in HL-60 cells. A: Dose-dependent effect of TRAIL on apoptosis quantitatively evaluated by flow cytometry after Annexin V/PI staining in HL-60 cells. Cells were cultured for $\mathbf{2 4}$ hours with the indicated concentrations of TRAIL. B: HL-60 cells were incubated with optimal concentrations (22 $\mu \mathrm{g} / \mathrm{mL}$ ) of PKC- $\varepsilon$ activator (act) or inhibitor (inh) peptides, used alone or in combination with recombinant TRAIL $(0.1 \mu \mathrm{g} / \mathrm{mL})$ and the percentage of apoptosis was assayed by counting the number of Annexin $V$ positive cells. In $A$ and $B$, data represent the means \pm SD of five independent experiments performed in duplicate. ${ }^{\star} p<0.05$. C: PARP cleavage was also analyzed as apoptotic marker. The full-length (115 kDa) and the cleaved forms (80 kDa; arrowhead) of PARP of a representative experiment are shown. Actin staining is shown as loading control. For both flow cytometry (B) and Western blot analysis (C) scrambled (scr) peptides were used as negative controls. UNT = untreated cells. 


\section{Discussion}

In this study, we have demonstrated for the first time that $\mathrm{PKC}-\varepsilon$ activation significantly counteracted the differentiation program induced by TNF- $\alpha$ along the monocytic lineage. This aspect of $\mathrm{PKC}-\varepsilon$ activity was not described before and it has important therapeutic implications since induction of mortality by terminal differentiation represents an alternative approach to cytodestruction of cancer cells by conventional antineoplastic agents, and has important biological implications. In this respect, retinoid acids are well known inducers of granulocytic differentiation of primary acute promyelocytic leukemia (APL) blasts and leukemic cell lines (Chambon, 1994). However, while some retinoids are currently used in the treatment of the M3-type of $A M L$, agonists such as vitamin D3, able to induce monocytic differentiation in other subtypes of $A M L$ and in particular in M4- and M5-types, did not demonstrate efficacy in clinical trials performed in AML patients, mainly due to a secondary hypercalcemia thus limiting the dose of vitamin D3 that could be administered (Bar-Shavit et al., 1983).

While the PKC-E inhibitor peptide showed negligible effects on the TNF- $\alpha$-mediated induction of leukemic maturation, this does not exclude that the association of $\mathrm{PKC}-\varepsilon$ inhibitor peptide and promaturative drugs might represent an important therapeutic combination. In this respect, it is also noteworthy that both $\mathrm{PKC}-\varepsilon$ inhibitor and activator peptides were able to significantly modulate the degree of apoptosis induced by TRAIL. The resistance of leukemic cells to currently used therapies occurs in part because leukemic cells safeguard their survival through mechanisms that allow them to escape death receptor-mediated apoptosis (Hanahan and Weinberg, 2000). Much attention has recently attracted the TNF family member TRAIL for its ability to overcome resistance to apoptosis in several tumors, including hematological malignancies (Secchiero and Zauli, 2008). While several studies have demonstrated that TRAIL resistance in a variety of hematological malignancies is mainly due to constitutively high levels of c-FLIP or low levels of TRAIL receptors (Secchiero and Zauli, 2008), we have here demonstrated that also the selective activation of the PKC- $\varepsilon$ family member can markedly counteract the susceptibility to TRAIL cytotoxicity in the sensitive HL-60 cell line. Our current findings are in line with those recently described by Gobbi et al. (2009), who demonstrated that $\mathrm{PKC}-\varepsilon$ activation by phorbol esters confers resistance to apoptosis induction in the K562 leukemic cell line. However, an important differences between the study of Gobbi et al. (2009) and our current data is that we have used inhibitor and stimulatory peptides which might have important future clinical applications. In fact, Yonezawa et al. (2009) have recently reviewed the potential use of PKC- $\varepsilon$ specific peptides developed by important pharmaceutical companies, which specifically inhibit PKC- $\varepsilon$ and ameliorate pathological conditions in a rodent insulin resistance model.

In summary, we propose that the ability of PKC$\varepsilon$ to promote leukemogenesis might be twofold: on one hand, it protects from TRAIL mediated apoptosis, perhaps by down-regulating Bid as demonstrated in other cancer cell models (Sivaprasad et al., 2007) and, on the other hand, it counteracts maturation along the monocytic lineage. Although the physiological stimuli able to activate $\mathrm{PKC}-\varepsilon$ in the bone marrow context are unknown, it is noteworthy that leukemic cells, like normal hemopoietic cells, survive and proliferate in the context of bone marrow niches ( $\mathrm{Li}$ and Neaves, 2006), it will be of interest to investigate the effect of cell-to-cell contact between bone marrow stromal cells and leukemic cells on the activation state of PKC- $\varepsilon$. Thus, while a potential role of $\mathrm{PKC}$ isoforms and in particular of $\mathrm{PKC}-\varepsilon$ in promoting tumorigenesis has been previously proposed, the novelty represented by this study is that we have demonstrated that PKC- $\varepsilon$ not only affect leukemic cell survival but also leukemic maturation. Moreover, a clinical implication of our study is that selective inhibition of PKC- $\varepsilon$ with inhibitor peptides, either to drugs able to induce maturation or to death inducing ligands or to combination thereof, should be taken into account in order to improve their therapeutic potential.

\section{Acknowledgments}

This work was supported by grants from CrTrieste Foundation.

\section{References}

Bar-Shavit Z, Teitelbaum SL, Reitsma P, Hall A, Pegg LE, Trial J, et al. Induction of monocytic differentiation and bone resorption by 1,25-dihydroxyvitamin D3. Proc Natl Acad Sci USA 1983; 80:5907-11. 
Borgatti P, Mazzoni M, Carini C, Neri LM, Marchisio M, Bertolaso L, et al. Changes of nuclear protein kinase $C$ activity and isotype composition in PC12 cell proliferation and differentiation. Exp Cell Res $1996 ; 224: 72-8$

Borgatti P, Zauli G, Colamussi ML, Gibellini D, Previati M, Cantley LL, et al. Extracellular HIV-1 Tat protein activates phosphatidylinositol 3- and Akt/PKB kinases in CD4+ T lymphoblastoid Jurkat cells. Eur J Immunol 1997; 27:2805-11.

Brandman R, Disatnik MH, Churchill E, Mochly-Rosen D. Peptides derived from the $\mathrm{C} 2$ domain of protein kinase $\mathrm{C}$ epsilon (epsilon $\mathrm{PKC}$ ) modulate epsilon $\mathrm{PKC}$ activity and identify potential proteinprotein interaction surfaces. J Biol Chem 2007; 282:4113-23.

Braun MU, Mochly-Rosen D. Opposing effects of delta- and zeta-protein kinase $\mathrm{C}$ isozymes on cardiac fibroblast proliferation: use of isozyme-selective inhibitors. J Mol Cell Cardiol 2003;35:895-903.

Breitman TR, Selonick SE, Collins SJ. Induction of differentiation of the human promyelocytic leukemia cell line $(\mathrm{HL}-60)$ by retinoic acid. Proc Natl Acad Sci USA 1980;77:2936-40.

Chambon $P$. The retinoid signaling pathway: molecular and genetic analyses. Semin Cell Biol 1994;5:115-25.

Dorn GW 2nd, Souroujon MC, Liron T, Chen CH, Gray MO, Zhou HZ, et al. Sustained in vivo cardiac protection by a rationally designed peptide that causes epsilon protein kinase C translocation. Proc Nat Acad Sci USA 1999;96:12798-803.

Gillespie S, Zhang XD, Hersey P. Variable expression of protein kinase $C$ epsilon in human melanoma cells regulates sensitivity to TRAILinduced apoptosis. Mol Cancer Ther 2005;4:668-76.

Gobbi G, Mirandola P, Carubbi C, Micheloni C, Malinverno C, Lunghi $P$, et al. Phorbol ester-induced PKCepsilon down-modulation sensitizes AML cells to TRAIL-induced apoptosis and cell differentiation. Blood 2009; 13:3080-7.

Gonelli A, Mischiati C, Guerrini R, Voltan R, Salvadori S, Zauli G. Perspectives of Protein Kinase C (PKC) Inhibitors as Anti-Cancer Agents. Mini Rev Med Chem 2009; 9: 498-509.

Hanahan D, Weinberg RA. The hallmarks of cancer. Cell 2000; 100:5770.

Johnson JA, Gray MO, Chen CH, Mochly-Rosen D. A protein kinase C translocation inhibitor as an isozyme-selective antagonist of cardiac function. J Biol Chem 1996;271:24962-6.

Li B, Kaetzel MA, Dedman JR. Signaling pathways regulating murine cardiac CREB phosphorylation. Biochem Biophys Res Commun 2006;350:179-84.

Li L, Neaves WB. Normal stem cells and cancer stem cells: the niche matters. Cancer Res 2006; 66:4553-7.

Lu D, Huang J, Basu A. Protein kinase Cepsilon activates protein kinase B/Akt via DNA-PK to protect against tumor necrosis factoralpha-induced cell death. J Biol Chem 2006;281:22799-807.

Milani D, Zauli G, Rimondi E, Celeghini C, Marmiroli S, Narducci P, et al. Tumour necrosis factor-related apoptosis-inducing ligand sequentially activates pro-survival and pro-apoptotic pathways in SK-NMC neuronal cells. J Neurochem 2003;86:126-35.

Mirandola P, Gobbi G, Ponti C, Sponzilli I, Cocco L, Vitale M. PKCepsilon controls protection against TRAIL in erythroid progen- itors. Blood 2006;107:508-13.

Okhrimenko H, Lu W, Xiang C, Hamburger N, Kazimirsky G, Brodie C. Protein kinase $\mathrm{C}$-epsilon regulates the apoptosis and survival of glioma cells. Cancer Res 2005;65:7301-9.

Racke FK, Wang D, Zaidi Z, Kelley J, Visvader J, Soh JW, et al. A potential role for protein kinase $\mathrm{C}$-epsilon in regulating megakaryocytic lineage commitment. J Biol Chem 2001;276:522-8.

Secchiero P, Gonelli A, Mirandola P, Melloni E, Zamai L, Celeghini C, et al. Tumor necrosis factor-related apoptosis-inducing ligand induces monocytic maturation of leukemic and normal myeloid precursors through a caspase-dependent pathway. Blood 2002; 100:2421-9.

Secchiero P, Milani D, Gonelli A, Melloni E, Campioni D, Gibellini D, et al. Tumor necrosis factor (TNF)-related apoptosis-inducing ligand (TRAIL) and TNF-alpha promote the NF-kappaB-dependent maturation of normal and leukemic myeloid cells. J Leukoc Biol 2003; 74:223-32.

Secchiero P, Zerbinati C, Melloni E, Milani D, Campioni D, Fadda R, et al. The MDM-2 antagonist nutlin-3 promotes the maturation of acute myeloid leukemic blasts. Neoplasia 2007;9:853-61.

Secchiero P, Zauli G. Tumor-necrosis-factor-related apoptosis-inducing ligand and the regulation of hematopoiesis. Curr Opin Hematol 2008; 15:42-8.

Sivaprasad U, Shankar E, Basu A. Downregulation of Bid is associated with PKCepsilon-mediated TRAIL resistance. Cell Death Differ 2007; 14:851-60.

Souroujon MC, Mochly-Rosen D. Peptide modulators of protein-protein interactions in intracellular signaling. Nat Biotechnol 1998; 16:919-24.

Todd RF, Nadler LM, Schlossman SF. Antigens on human monocytes identified by monoclonal antibodies. J Immunol 1981;126:1435-9.

Vitale M, Zamai L, Falcieri E, Zauli G, Gobbi P, Santi S, et al. IMP dehydrogenase inhibitor, tiazofurin, induces apoptosis in $\mathrm{K} 562$ human erythroleukemia cells. Cytometry 1997;30:61-6.

Yonezawa $\mathrm{T}$, Kurata R, Kimura M, Inoko H. PKC delta and epsilon in drug targeting and therapeutics. Recent Pat DNA Gene Seq 2009; 3:96-101.

Zauli G, Visani G, Bassini A, Caramelli E, Ottaviani E, Bertolaso L, et al. Nuclear translocation of protein kinase $\mathrm{C}$-alpha and -zeta isoforms in $\mathrm{HL}-60$ cells induced to differentiate along the granulocytic lineage by all-trans retinoic acid. Br J Haematol 1996;93:542-50.

Zauli G, Pandolfi A, Gonelli A, Di Pietro R, Guarnieri S, Ciabattoni G, et al. Tumor necrosis factor-related apoptosis-inducing ligand (TRAIL) sequentially upregulates nitric oxide and prostanoid production in primary human endothelial cells. Circ Res 2003;92:73240.

Zauli G, Secchiero P. The role of the TRAIL/TRAIL receptors system in hematopoiesis and endothelial cell biology. Cytokine Growth Factor Rev 2006;17:245-57.

Zhang DE, Hetherington CJ, Gonzalez DA, Chen HM, Tenen DG. Regulation of CD14 expression during monocytic differentiation induced with 10,25-dihydroxyvitamin D3. J. Immunol 1994;153: 3276-84. 